\title{
Suhard Massif. A geomorphological study
}

\author{
Liviu CARP ${ }^{1^{*}}$ \\ ${ }^{1}$ Department of Geography, „Ștefan cel Mare” University of Suceava, Romania \\ * Correspondence to: Liviu Carp, Department of Geography, „STtefan cel Mare” University of Suceava, Romania. E-mail: \\ liviucarp@yahoo.co.uk.
}

\section{Article history}

Received: December 2012

Received in revised form:

January 2013

Accepted: February 2013

Available online: May 2013
ABSTRACT: Suhard Mts., part of the Northern Carpathians, stretch over an area of $323 \mathrm{sq} \mathrm{km}$, in the shape of a northwest-oriented ridge. This massif is composed of crystalline schists (meso- and epimetamorphic), as well as sedimentary rocks pertaining to the trans-Carpathian flysch deposits (i.e. various types of sandstone, conglomerates and marls) in the southwestern sector. Whereas this region is characterized by the occurrence of a wide range of carbonate rocks, we noted the scarcity of karst forms. Geological survey maps of the area indicate the occurrence of few folded structures; moreover, the massif is mostly part of an ample anticline whereby the axis underlies the valley of Bistrita Aurie river, accompanied by a large syncline underlying Cosna river valley (tributary of Dorna river). The prevalence of crystalline rocks within this anticlinorium results in the overall massif shape of these mountains (hence, the name), which is the foundation for the detail structural and lithological relief forms. The array of structural relief forms includes structural plateaus on sedimentary and crystalline carbonate rocks, and steep slopes in the form of both hogbacks and overthrust scarps. The lithological relief occurs primarily as a result of the contrasting chemical composition of various crystalline rocks, whereas sedimentary rocks seldom generate such forms and solely when favored by the structure, as well. Consequently, carbonate rocks are rather discrete and only stand out in the form of clints (lapies) and gorges, or hums. As regards the matter of denudation surfaces, which has proved rather difficult to solve, we were able to determine the presence of an erosion surface ranging from 1200-1300 m to $1500-1600 \mathrm{~m}$, wherein neotectonics played a significant role by fragmenting the original surface, particularly in the northwestern sector, where its fragments descend in the shape of consecutive steps towards Rotunda saddle. Periglacial modeling of the relief resulted in a variety of forms of both erosion (scarps, ridges, hums) and accumulation (scree) located in the highest areas, particularly along the main ridge (summit).

KEY WORDS: Suhard, lithology, structural relief, lithologic relief, periglacial relief

\section{Introduction}

The Bucovinean Suhard Massif pertains to the Northern group of the Eastern Carpathians (see fig. 1) as is regarded as a southeastern extension of the crystalline-Mesozoic massifs (Rodna- 
Maramures). This area was granted less attention in terms of geomorphological research as compared to the neighboring mountains, i.e. Rodna Mts, Maramures Mts and Obcinile Bucovinei. Brief reviews of the relief were published by Sircu (1971), where this massif is referred to under the name Obcina Suhard, as well as Velcea and Savu (1982), Popescu-Argeşel (1983) and lacob (1987). Within this context, the present paper aims to bring to light the distinctive features of the geomorphology of Suhard Massif, which distinguishes itself rather clearly from the neighboring mountainous units.

Thus, Bistrita Aurie valley demarcates the massif from Zimbroslavei and Jibău Mts to the North, and from Obcina Mestecăniş and Giumalău Massif to the East, respectively. To the South, Suhard Mts border on Dornelor Depression, from which they are separated by Dorna river valley up to the confluence with its tributary Doceni, whereas to the West, the boundary between the massif and the depression is located along the $950 \mathrm{~m}$ contour line following a contact glacis.

Further to the West, the massif is markedly delimited from Bârgău Mts by Coșna river valley up to its springs. Further on, the boundary crosses Suhard saddle $(1140 \mathrm{~m})$ and follows the valleys of Măria Mare and Măria to the confluence with Preluci stream, and continues to the North along the upper valley of Preluci up to Rotunda saddle $(1280 \mathrm{~m})$, proceeding onwards to the valley of Bistrița Aurie along its tributary Rotunda stream.

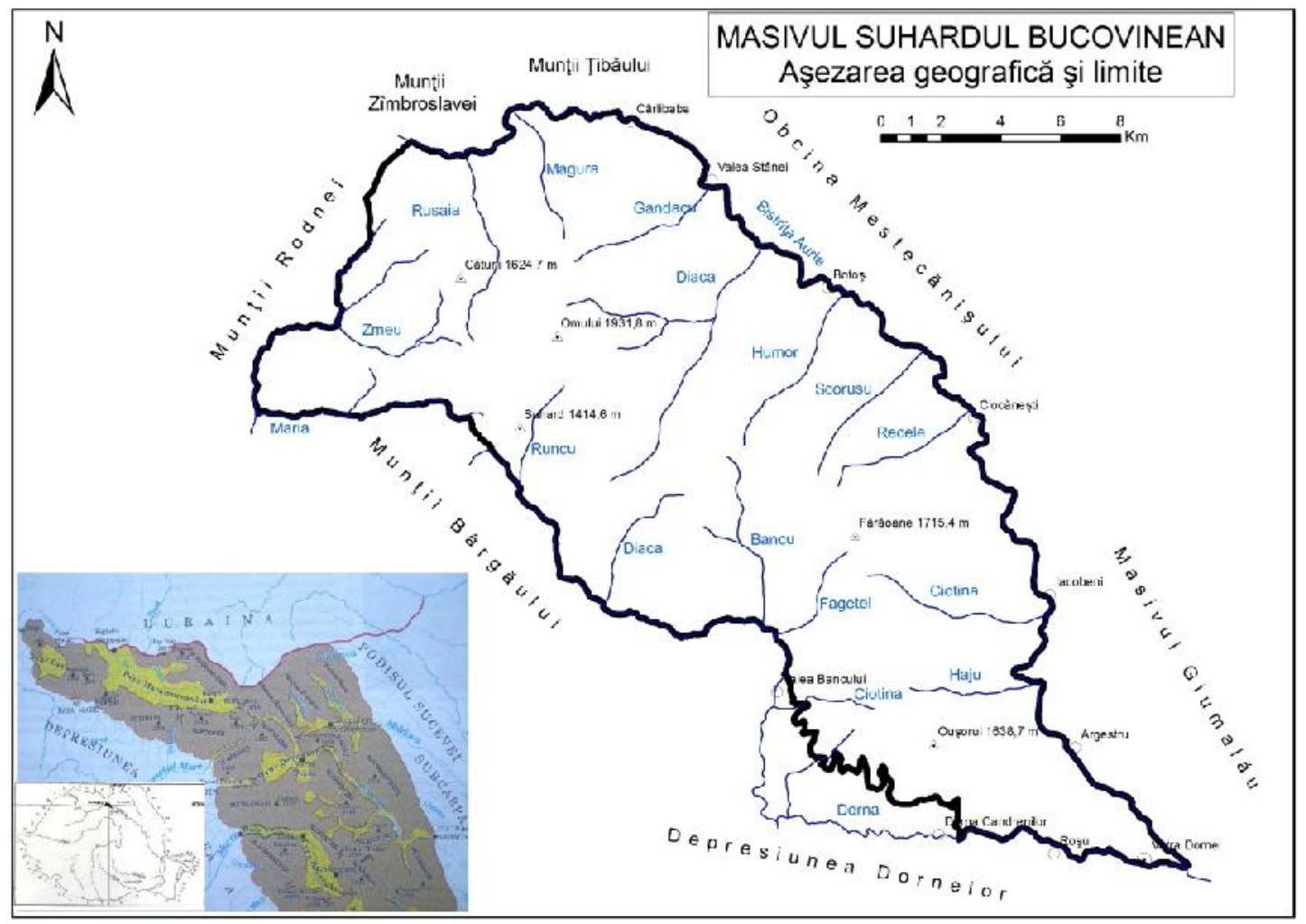

Figure 1. The location of (Bucovinean) Suhard Massif within the Northern Group of the Eastern Carpathians. This figure is available in colour online at www.georeview.ro. 


\subsection{Geology and climate of the study area}

The geological composition of Suhard Massif is complex, comprising mostly of crystalline systems (formations) (such as Bretila-Rarău, Rebra, Negrişoara, Tulgheş and Rusaia), but also a rather broad range of sedimentary formations pertaining to the trans-Carpathian flysch. We noted the wide occurrence of carbonate rocks, mainly crystalline limestone and dolomite, as well as the sedimentary forms, gradually making the transition from calcareous sandstones to sandy limestones. Within the crystalline area there are differences in terms of the degree of metamorphism; however, it is not a general rule that a higher degree of metamorphism will necessarily stand out in terms of the resulting relief. The climate falls into the medium-high mountains climatic range, i.e. the mean annual temperature ranges from $6^{\circ} \mathrm{C}$ at the mountain feet to $0,2^{\circ} \mathrm{C}$ at $1900 \mathrm{~m}$, and the mean annual amplitude at over $1700 \mathrm{~m}$ is $17,1^{\circ} \mathrm{C}$. At this elevation the other climatic parameters have the following mean annual values: duration of frost is 195 days, solid precipitation amounts to $45 \%$ of the total precipitation, duration of snow cover is 170 days, whereas the mean duration of sunshine is nearly $1150 \mathrm{~h}$.

\section{Objectives and methods}

The relief of Suhard Massif has some peculiar features which can be explained in the light of the most recent cartographic materials available and newer interpretations regarding the shaping of these features specific to the mountain area. Field research has been instrumental in reconfiguring some of the facts previously established in the literature, and ultimately describing as accurately as possible the most representative types of relief.

We conducted this research based on the available cartographic materials, the 1:25000 topographic survey maps, the 1:200000 (Rădăuți sheet) and 1:50000 (Vatra Dornei sheet) geological surveys and the Geomold archives in Câmpulung Moldovenesc. A sequence of specific steps, comprising of field research, mapping, measurements and inventorizing, has resulted in outlining the main geomorphological features of the study area.

\section{Results and discussion}

\subsection{Denudation surfaces}

The authors who investigated the geomorphology of the Northern group of the Eastern Carpathians identified various denudation surfaces; i.e. de Martonne (1922) recognized a range of slightly undulating surfaces located around 900-1000 m around Vatra Dornei urban area and rising imperceptibly up to 1200 m, whereas Sîrcu (1971) determined the occurrence of two denudation surfaces, namely Mestecăniș at 1200-1300 m and Poiana Ciungi (the equivalent of Cerbu, Upper Miocene) at 1500-1700 m, most likely extended to the Suhard, where the latter is overtopped by the highest peaks. Popescu-Argeșel (1983) listed two surfaces: un upper older level in the form of inselbergs with decreasing altitudes from the NW towards the SE: 1750-1900 $\mathrm{m}$ in Omu Massif, 1550-1700 m in Fărăoane Massif and around $1600 \mathrm{~m}$ in Oușoru Massif. The more recent erosion surface includes elevation values ranging from 1400 to $1500 \mathrm{~m}$ and has a peripheral development. Recent papers (Lesenciuc, 2006) document the presence of a single erosion surface including several steps, which resulted from neotectonic activity occurring at varying rates in some sectors. 
In Suhard we accept the existence of a single surface contained in the 1200-1600 m elevation range, whereby most of it ranges from 1400 to $1500 \mathrm{~m}$; however, compared to the total area of the massif, this surface is rather small. The sector between Mt Şveiţaria and Şuvir summit, as well as the one located to its South (separated by tributaries of Scorușu river) are a part of this surface. Located at $1550 \mathrm{~m}$, they are remarkably smooth and slightly sloping towards Bistrița Aurie valley. To the South, along the main summit we find the area bounded by Fărăoane and Tarnița peaks, exhibiting the same broad aspect, slighly sloping eastward. In the Northern and Southern sectors of the massif, the ruptural tectonics resulted in the fragmentation of this surface, such that the peripheral areas are only 1200-1300 m high; however, they are connectable with the neighboring crystalline units (Rodna and Giumalău Mts). Thus, the sectors located between Coșorbii peak and Rotunda saddle (see fig. 2) have a step-like layout, descending from 1600 to $1300 \mathrm{~m}$, in the form of at least 4 sectors separated by fault lines and overthrusts. The lowest step, in the vicinity of Rotunda saddle, overlies the post-tectonic sedimentary Flysch (Upper Cretaceous-Oligocene) and is delimited from the next step, i.e. Rotunda saddle, at $1350 \mathrm{~m}$, by the fault line between the Bucovinean Nappe and the posttectonic Flysch. Further South-East, a broad area located in the vicinity of Cosorbii peak at 1520$1550 \mathrm{~m}$ is separated from the previous one by the overthrust plane of the Bucovinean Nappe. Lastly, the highest step, located at $1580-1620 \mathrm{~cm}$ is delimited by the fault line connecting the Bucovinean and Sub-Bucovinean Nappes. On the opposite side of the massif, i.e. the Southern sector located between peaks Oușoru and Runs, the mean elevation of the surface is just $1200 \mathrm{~m}$.

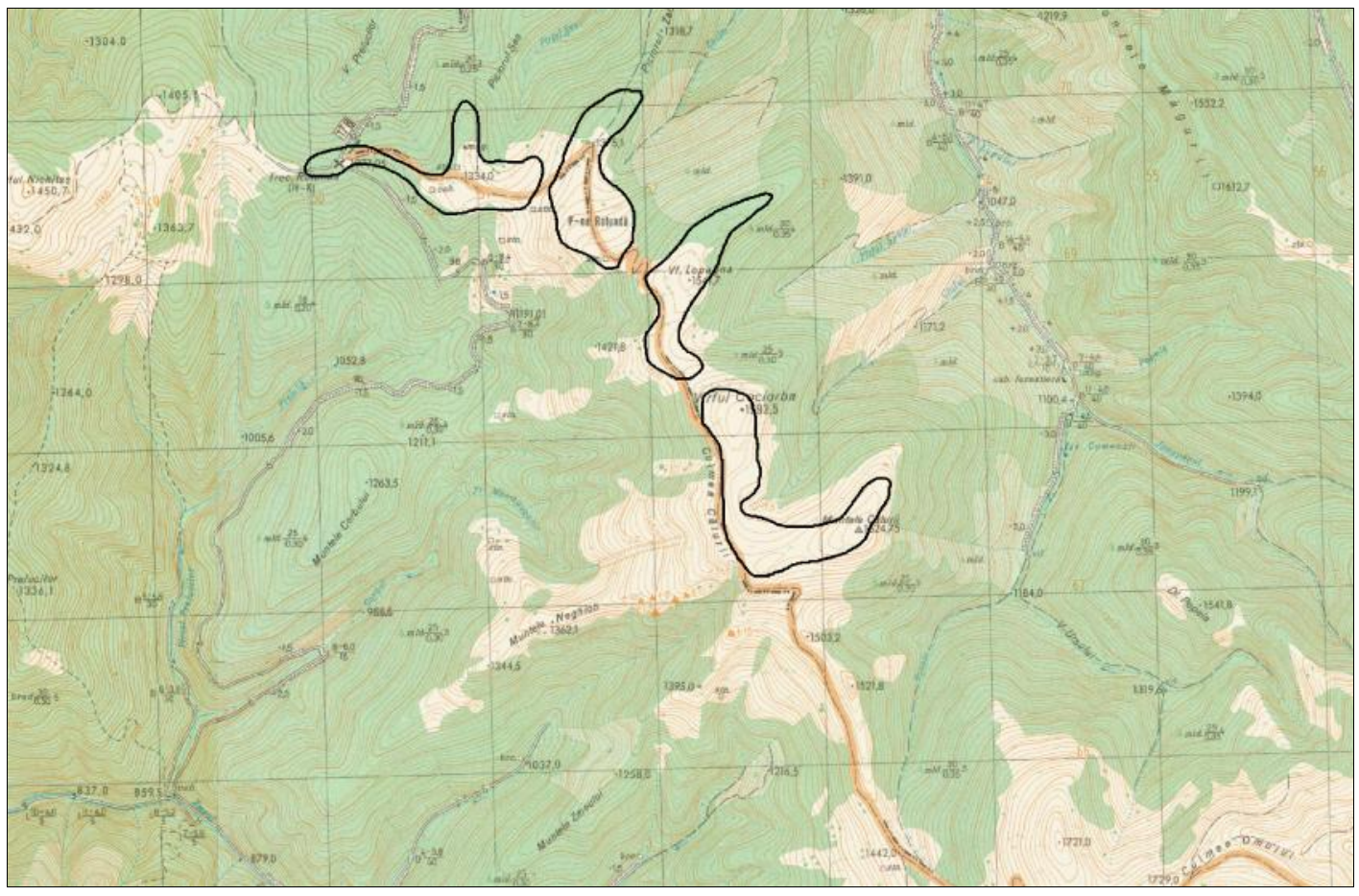

Figure 2. Denudation surfaces delimited on topographic map of Rotunda-Căturii area. This figure is available in colour online at www.georeview.ro.

As regards the existence of an upper level which should incorporate solely the main peaks, we are rather skeptical due to the lack of evidence to support this assertion. Furthermore, Sârcu (1979) does not acknowledge the existence of an upper surface in the Rodna Mts located in the near vicinity of Suhard, either. 


\subsection{The influence of structure on the relief}

Within the study area, geological research conducted by Săndulescu (1984) revealed the existence of two major folds, i.e. Rusaia anticline and lacobeni anticline, both oriented southeastward. However, the overall structure is relatively flat, with broad undulations and lowangled formations, up to maximum values of $25-30^{\circ}$ (Arhiva Geomold). The formation of structural relief is prompted by the structure comprising of overthrust folds, overthrust lobes and the fault system.

The structural surfaces are more apparent in areas with large outcrops of the Trans-Carpathian Flysch, including mainly the unit composed of Oușoru and Livada, which displays the traits of a sloping plateau towards Coșna stream in the SW. The size of the units belonging to this surface is rarely large; moreover, in some instances they have evolved into summits. However, it reappears in the form of a plateau in Mount Stejii, isolated as a result of the regressive advance to Ciotina (Coșna) stream, as well as the interfluve bounded by streams Diaca (Coșna) and Pietriș, whereby the appearance is emphasized by the local toponym Muntele Neted (eng. Smooth Mountain). Also, the upper sector of Mount Bindireasa is a structural plateau sloping southward. Another example is the ensemble composed of Mount Căturii and its hillslope descending towards the tributaries of Someșu Mare, highly sloping to the SW, which is a plateau shaped on Rebra crystalline dolomites and limestones.

The penetration of anticline structures by valleys results in the formation of steep slopes, as it is the case with Bistrița Aurie valley crossing Bretila anticline, in-between the confluences with streams Rusaia and Runcu in the North, and lacobeni anticline in Haju sector, in the South.

Hogbacks are a rarer occurrence in the landscape. One of these examples is Mount Oușoru, with the front facing Bistrița valley, which dominates the entire southern sector of the massif, including the crystalline area (considering the ample overthrust of the Trans-Carpathian Flysch over the crystalline). Similar structures developped on limestone occur in the southwestern flank of Căturii peak, whereby the limestone strata incline in the same direction, thereby confirming the influence of structure on the relief.

As regards the relation between the valleys and the overall structure, several situations arise, i.e. longitudinal, diagonal or transverse valleys.

The former type of valley follows the direction of large Carpathian structures (which have a general NW-SE orientation), as is the case with Bistrița Aurie valley downstream of the confluence with Țibău up to Vatra Dornei, where the river valley overlays an anticline. On the opposite side, Coșna river has most of its channel length along a broad anticline with the same orientation (NW-SE), discontinued only by the outcrop of Măgura Coșnei intrusive subvolcanic body.

Transversal valley sectors are rather frequent. In the study area, large sectors of rivers ranking differently in the Strahler system (1952) (e.g., several direct tributaries of Bistrița and Coșna) have almost normal confluence angles with the respective longitudinal valleys, and are thus likely to develop quasi-transversal valleys.

The tributaries Bistrița Aurie receives upstream of the junction with Țibău have an apparent transversal character in the northern and southern sectors, respectively, where they cross over folded structures, i.e. anticlines, whereas in their central sectors this aspect is not as apparent. Both Ciotina and Haju streams have typical transversal valleys (due to their crossing an anticline) and their middle sectors undergo visible narrowing of the valleys. A similar situation occurs on 
the southwestern slope of Oușoru Massif, where tributaries of Coșna river (Ciotina, Catariga and Izvorul Alb - solely in its upper sector) cross the flanks of the syncline centered on Coșna valley.

\subsection{The influence of lithology on the relief}

Research conducted on the morpho-lithology of the study area shows the following main geomorphological types: relief developped on crystalline schists; relief formed on carbonate rocks; and relief developped on conglomerates and sandstones.

The relief formed on crystalline schists is prevalent in Suhard Massif; these schists commonly behave as an ensemble of hard rocks, displaying lower sensitivity to chemical reactions compared to sedimentary rocks (Ilie, 1957). Thus, the micaschists from the Bretila group, despite their age and high degree of metamorphism are not prominent in the relief and their quartz content is rather low, ranging from $20-40 \%$. Rebra micaschists, which are comparatively harder and have a higher content of quartz, have a different appearance in the morphological landscape and are more common in the northern sector. These rocks support the highest altitudes in Suhard, both in the north: Omu (1931 m), Runcu (1775 m), Pietrele Roşii (1773 m), Stânişoara (1698 m), Coşorbii $(1592 \mathrm{~m})$, and the central sector, in the case of several peaks of approx. $1600 \mathrm{~m}$ up to 1714 m (Fărăoane peak). Furthemore, Mount Fărăoane is an example of inselberg composed of alternating micaschists and crystalline dolomites, and stands out as such against the landscape. Also rather prominent are the ensembles Pietrele Roșii - Runcu peaks (Mount Omu) and Mount Stânișoara due to their high content of quartz micaschists.

Crystalline dolomites are the main carbonate component of the Rebra group, and are commonly associated with crystalline limestones. Their occurrence results in the formation of specific relief forms in the NW sector, i.e. narrow valley sectors and gorges, and peculiar structural relief forms in Căturii peak area, as well as numerous hums on its SW hillslope. In the central sector crystalline dolomites are locally associated with micaschists along the main ridge and stand out in the shape of conical peaks: Bâtca Târşului peak (1548 m), Şveiţaria (1562 m), Muntele Târş (1360 $\mathrm{m})$. Furthermore, the hums carved in carbonate rocks which discontinue the typical monotony of the crystalline rocks are rather spectacular. They are located on the flanks of the main summit of the massif, between Şveiţaria and Fărăoane peaks, as well as on the western flank of Mount Coșorbii, towards Mount Neghiob, in the form of hums with various shapes (ranging from walls to columns up to $10 \mathrm{~m}$ high) arising from the natural meadows.

Quartz-sericite-chlorite schists (including the sericite-chlorite variety) have a variable content of quartz, ranging from 40 to $70 \%$, and are representative for several lithological groups, such as Rusaia (where they are emphasized in the relief solely due to the presence of a convex structure - Mount Măgurii, 1500-1683 m) and Tulgheș (whereby the higher quartz content results in more prominent heights, as in the case of the main summit between Fărăoane and Tarnița peaks, at over $1500 \mathrm{~m}$ ).

Graphite schists and graphite-sericite schists pertaining to the Tulgheș group have a lower content of quartz and occur on the valley slopes of several tributaries of Bistrița Aurie. Hard porfiroide gnaisses (Negrișoara group) outcrop in summits with higher elevations: Tarniţa peak 1542 m, Mount Ştefan - 1341 m, Obcina Dieci - 1449 m. Various types of particularly hard quartzites (black, white, grey) only occur rather seldom and locally, as in the case of Bistrița valley at Tolovanu, resulting in the formation of thresholds in the thalweg. 
Acid rhyolite metatufa pertaining to the Tulgheș group, along with quartzite schists, participate in shaping rather prominent peaks, such as Icoana $(1592 \mathrm{~m})$ and the ridge separating streams Gândac and Stânişoara (1431 m).

As regards the valleys, it was determined that crystalline rocks favoured the development of relatively short narrow valley sectors both on Bistrița Aurie and its direct and indirect tributaries. Grigore (1989) identified five such narrow sectors carved in metamorphic rocks (epi- and mesometamorphic). Between these gorges are interposed sectors where they valley broadens considerably, up to creating small depressions such as Cârlibaba, Botoş, Ciocăneşti, lacobeni. Also present are small confluence depressions (Rotunda, Valea Stânei).

The relief formed on carbonate rocks (karst) in Suhard Massif formed on crystalline dolomites pertaining to the Rebra group, as well as crystalline limestones (Rebra, Rusaia). Some specific forms also occur in the SW part of the study area, in Coșna basin, on calcareous conglomerates and sandstones, conglomerate and bituminous limestones etc (Middle Eocene).

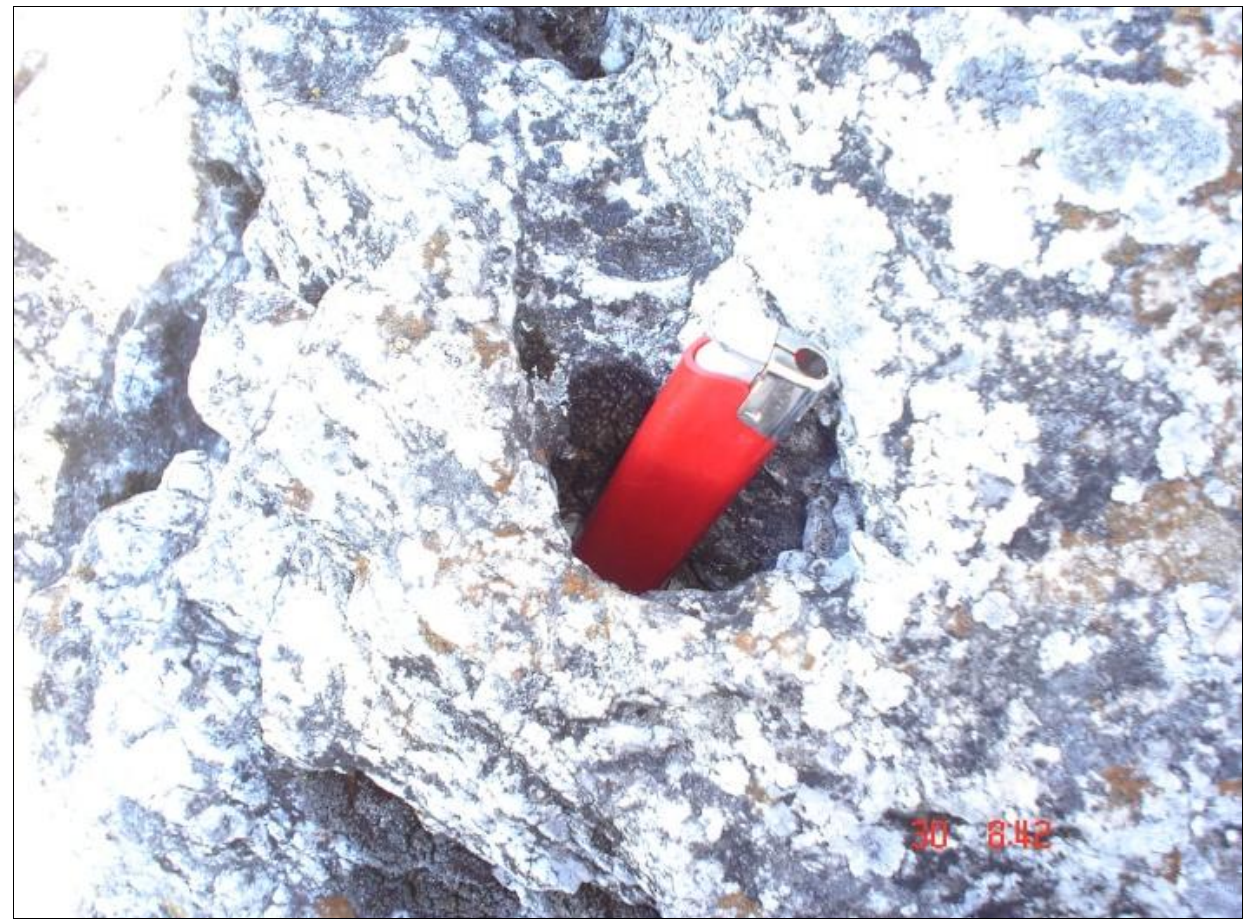

Figure 3. Tubular lapies in Bâtca Târşului (photo L. Carp). This figure is available in colour online at www.georeview.ro.

Among the forms of the karst relief occurring in the study area, lapies (see fig. 3) are found in the vicinity of Suhard peak and in Mount Stânișoara, Bâtca Târşului peak (the tubular form), whereas the lapies formed on the calcareous limestones located near Oușoru peak are considerably smaller in size.

Gorges. A very interesting gorge was identified on the upper course of Neghiob stream, part of the Someș river basin, which formed under the control of a very low base level of Someș by deepening of the channel in the Rebra dolomites (from the Bucovinean Nappe). The depth of the valley in the gorge sector is max. $10 \mathrm{~m}$.

Within the gorges the valley slopes have various slope gradients; in some cases, small overhangs formed wherever layers of harder rocks occurred in the context of a friable ensemble. The long 
profiles show the presence of thresholds and emerging sinkholes. Hums, commonly columnshaped, have numerous protrusions resulting from differential erosion on unevenly cemented strata or diaclase lines on limestones, and are a dominant feature on the SW slope of Mount Căturii, in the shape of an ensemble of large-shaped isolated forms dispersed on the entire slope towards Mount Neghiob. We believe these are hums detached from the mass of Rebra crystalline rocks through a complex process implicating both the lithological traits and denudation. Within the valley of Neghiob stream we identified such hums composed of harder rocks which are currently being detached from the hillslope mass (in various stages of the process) and we predict that as the process will advance they will remain isolated on the slope.

As regards the influence of lithology on the morphology of valleys, the alternance of narrow sectors with broader ones due to lithological variations is of particular interest. We mentioned before the presence of five narrow sectors on Bistrița Aurie river (Grigore, 1989), between which several wider sectors and even small depressions are interposed (Cârlibaba, Botoş, Ciocăneşti, lacobeni).

The relief formed on sandstone and conglomerates. In the study area these forms occur in Mount Oușoru, Mount Bindireasa, and the basins of Măria Mare and Coșna rivers due to the outcrop of the Trans-Carpathian flysch. The local alternance of sandstones and marnes results in low gradient slopes, and the occurrence of superficial landslides and petrographic tors, in some cases (the right-side valley slope of Măria river). Eocene calcareous conglomerates accompanied by conglomerate limestones, which are harder, support the Oușoru-Livada ensemble, $300 \mathrm{~m}$ higher compared to the crystalline area.

The periglacial relief from Suhard Massif includes a wide variety of forms. We identified periglacial cliffs in the higher areas of the massif, in Omu peak, just below the maximum elevation, in Pietrele Roşii, Muntele Fărăoane, with the appearance of a vertical wall approx. 250$300 \mathrm{~m}$ high. Somewhat smaller sized cliffs are found below Oușoru and Livada peaks.

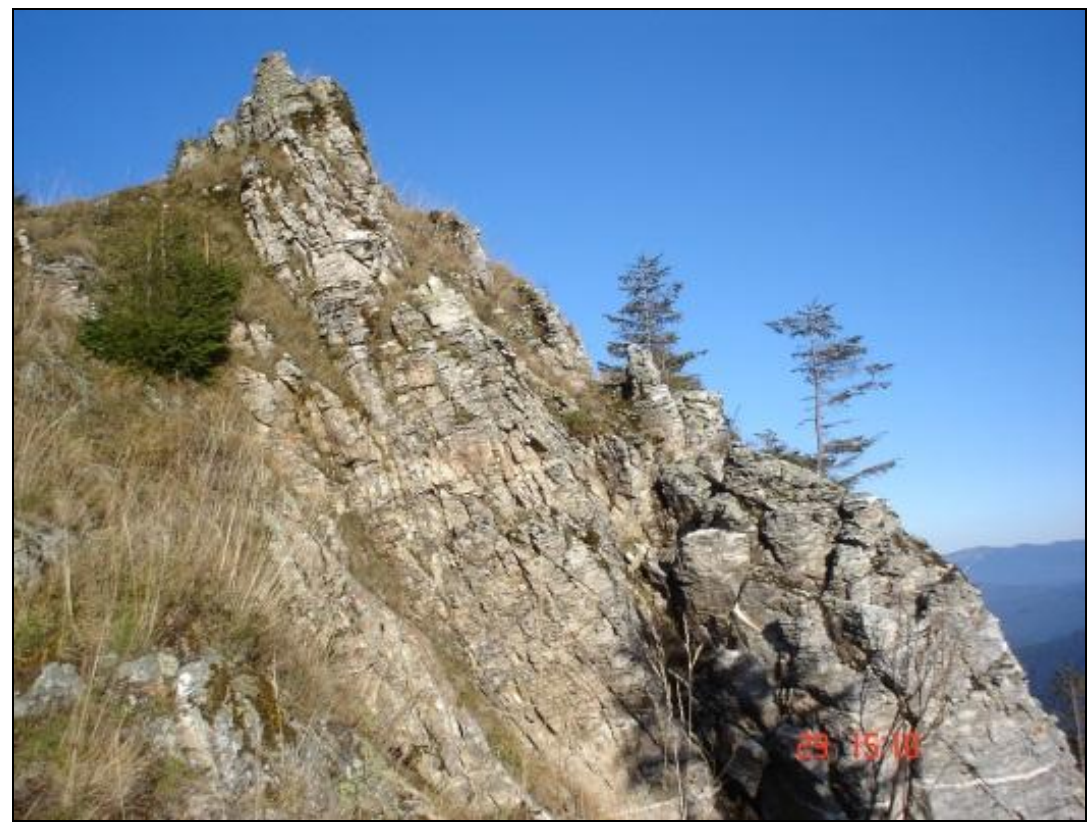

Figure 4. Periglacial tor (Mt. Târș). This figure is available in colour online at www.georeview.ro. 
Along the main summit several sectors have developped as a periglacial ridge, as in the case of Pietrele Roşii-Runcu, Căturii saddle, Fărăoane peak and partially Omu peak, as well as on the ridge separating streams Runcu and Măria Mare. The same forms, albeit to a smaller extent, are found on the secondary summits, such as Stânişoara, Suhard, Poiana Humorului. Periglacial tors are widespread in various forms and shapes (fig. 4), both along the main summit (Omu, Pietrele Roşii, Diecilor, Icoana, Bâtca Târşului, Fărăoane, Tarniţa) and on the secondary ones (particularly Stânişoara and Suhard), but also on hillslopes. Ventifacts are also present in the Suhard Massif (fig. 5) with the same shapes like in Jibău Mts (pers. comm. M. Mîndrescu, 2012).

Relatively small sized screes are found in the vicinity of several peaks, such as Omu (scree fields similar to those located in Călimani Mts), Stânișoara, Fărăoane (chaotic boulders), Oușoru (moslty fixed screes). Rather numerous ploughing boulders were identified nearby Bâtca Târșului peak in Mount Stânișoara. Other forms, such as nival niches, were found (Popescu-Argeșel, 1980) in the the main summit area - Omu peak, South of Fărăoane, on the Northern slope of Stânișoara summit, North-East of Bâtca Târşului peak. Sircu (1979) questions the formation of these features as a result of snow activity, and more recently, Mîndrescu and Cristea (2011) use the term sackung (antislope scarps/slope pockets) to denominate them, and believe they resulted from gravitational deformation and reconfiguration by snow.

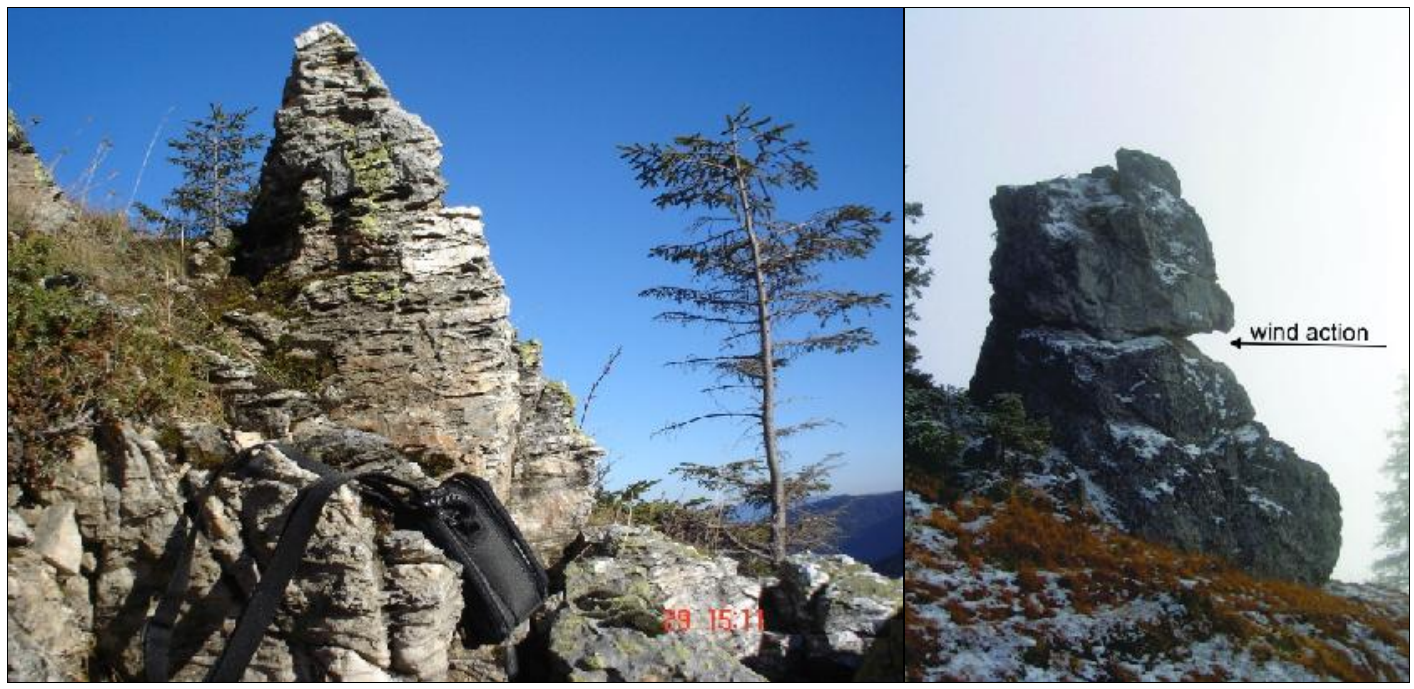

Figure 5. Example of ventifact in Suhard Mts (Mt. Târș - right; photo: L. Carp) and Tibău (left; photo: M. Mîndrescu). This figure is available in colour online at www.georeview.ro.

Sackungs are the largest gravitational deformations observed in mountains and are characterized by the long-term slowness of the movements, but their mechanism is still not well understood; however, cosmic ray exposure (CRE) dating methods allow dating the morphologic structures involved in sackung and can contribute at the understanding of their origin (Hippolyte et al., 2009). This category of forms includes two examples deserving of special attention, i.e. the sackung located West of Omu peak which is significant due to its size which resulted in its being considered a "miniature" cirque by Sîrcu, and the one located just below Icoana peak, hosting a lake.

In the first case we agree with Mîndrescu and Cristea regarding the possible implication of gravitation, whereas in the case of Icoana lake, a large-scale landslide created a depression between the landslide body and the back-scar, which is currently infilled by the lake and continues further towards the omonimous peak (fig. 6). Mîndrescu and Cristea (2011) raise the 
question of a gravitational fault senso Sîrcu (1979); based on this viewpoint, we believe the feature we identified in Mount Fărăoane area (length of 18-20 m and depth 2-3 m) and formerly considered a nival niche (Rom. scochina) may have resulted from a gravitational process, as well. Such gravitational features formed post- deglaciation or later on as a result of gravitational decompression of the slopes and short- and medium-term freeze-thaw cycles (Mindrescu and Cristea, 2011).

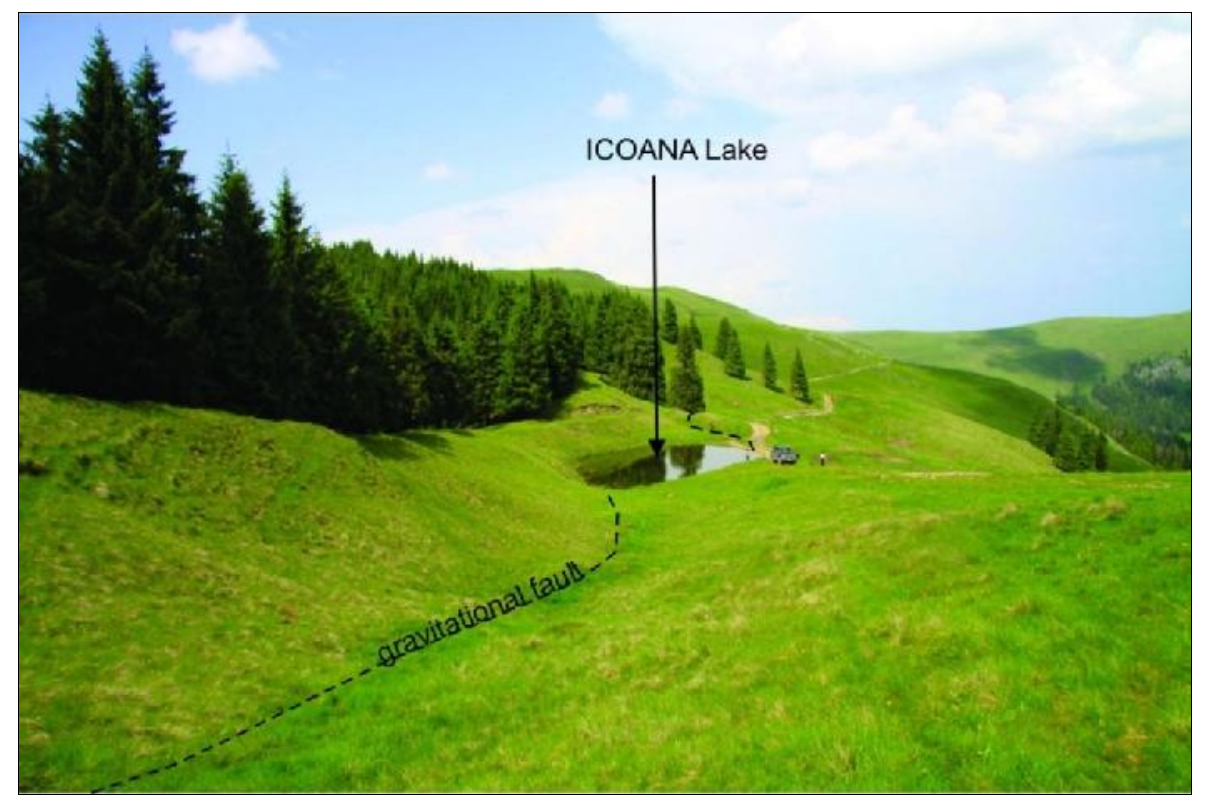

Figure 6. Lake Icoana - view from the West (photo modified by M. Mîndrescu). This figure is available in colour online at www.georeview.ro.

\section{Conclusions}

The aim of this research was to identify relief features within Suhard Massif which had not been previously analysed (structural and petrographic relief) or were just briefly mentioned in the literature (denudation surfaces, periglacial relief ) in order to elaborate a complex study on the geomorphology of this mountain unit. As regards the former category, we related the available geological data with our field observations, thus acquiring a relatively detailed view on the structural and petrographic traits of the study area. Regarding the latter category we used a comparative approach by relating our observations to data regarding the neighboring mountainous areas and the latest developments reported in the literature. Thus, considering the variety of the lithological composition (both crystalline and sedimentary) and the chemical differences within the same types of rock, it is apparent that these factors will create a wide range of petrographic forms. Moreover, the structural differences further reflected on the relief, contributing to the formation and delimitation of distinct divisions, whereas the modeling generated by past and present climate factors links this massif to the entire ensemble of the Eastern Carpathians.

Suhard Massif is a medium-high mountain where denudational processes specific to the fluvialdenudational level are prevalent, to which is added a narrow fringe undergoing crionival 
processes. The latter category of processes, including particularly the freeze-thaw cycles and wind abrasion, generated the most spectacular features in this massif, i.e. periglacial tors, ventifacts, scree cones etc. However, the main linear dislevelments, misinterpreted as nival niches (Rom. scochine) are a result of gravitational decompression; some of these features are occupied by small elongated lakes, indicating the type and shape of the slope ruptures near the watershed. Despite its maximum elevation of over $1900 \mathrm{~m}$, Suhard Massif does not display any evidence of the existence of Pleistocene glaciers, most likely due to its location in the shade of Rodna Mts.

\section{Acknowledgements}

I greatly appreciate the coordination of Prof. Costica Brânduş in elaborating my PhD thesis, and the useful suggestions and comments from Dr. Marcel Mîndrescu.

\section{References}

Antonescu F., Paidiu P., Savu M. 1978. Raport final privind cercetările geologice din regiunea Coşna-Teşna. Arhiva IPEGH, Bucureşti.

Balintoni I., 1984. Structure of the right side of the Bistriţa River between Ciocăneşti and Vatra Dornei. (East Carpathians). D.S. Inst. Geol. Geofiz. LXIII/5, Bucureşti.

Barbu N., 1976. Obcinele Bucovinei. Editura ştiinţifică şi enciclopedică, Bucureşti.

Bercia I., Bercia Elvira, Săndulescu M., Szasz L. 1975. Harta geologică, Scara 1:50000. Foaia Vatra Dornei. Inst. Geol. Rom., Bucureşti.

Dumitrescu I., Săndulescu M. 1968. Probleme structural fundamentale ale Carpaţilor Româneşti şi vorlandul lor. An. Com. Geol. t. XXXVI, Bucureşti.

Dimitrescu R. 1960. Observaţii privind depozitele mezozoice şi tectonica regiunii lacobeni. S.S.N.G., Comunic. Geol-Geogr. vol. I, Bucureşti.

Erhan V. 1981. Contribuţii la determinarea condiţiilor fizice ale metamorfismului din compartimentul moldav al Carpaţilor Orientali pe baza studiului mineralotermometric. An. Şt. ale Univ. Al.I. Cuza, Iaşi.

Erhan V., Popa GHE. 1967. Studiu petrografic şi chimic al carbonatitelor din unitatea epimetamorfică centrală cuprinsă între Valea Bistriţei şi Valea Putnei. An. Şt. ale Univ. Al.I. Cuza, laşi.

Filipescu G. M. 1967. Geologia Carpaţilor Orientali. St. şi Cercet. de Geol. Geofiz. Geogr. Seria Geol. vol. XII, nr. 1, Bucureşti.

Grigore M. 1989. Chei, defileuri şi văi de tip canion din România. Editura Ştiinţifică şi Enciclopedică, Bucureşti.

Hippolyte, J-C., Bourlès, D., Braucher, R., Carcaillet, J., Arnold, M., Aumaitre, G., Léanni, L. 2009. Cosmogenic $10 \mathrm{Be}$ dating of a sackung and its faulted rock glaciers, in the Alps of Savoy (France). Geomorphology, 108, 312-320.

Joja T., Alexandrescu Gr. Bercia I., Mutihac V., Dimian M. 1968. Harta geologică. Scara 1:200000. Foaia Rădăuţi. Inst. Geol. Rom., Bucureşti. 
Lesenciuc C.D. 2006. Masivul Giumalău. Studiu geomorfologic. Editura Tehnopress, laşi.

Kräutner Th. 1968. New concepts on the metamorphic massif of Rodna (in Romanian). Studii si cercetari de geologie, geofizica si geografie. Geology v. 13, Bucharest.

Kräutner Th., Kräutner F. 1974. Litostratigrafia seriei de Tulgheş, din pânza de Putna,în regiunea Botuş-Breaza (Carpaţii Orientali). D. S. Inst. Geol. Geofiz. vol LX/1, Bucureşti.

Mîndrescu M., Cristea A. I. 2011. Rock mass failures and antislope scarps in the Northern Romanian Carpathians, Carpatho-Balkan-Dinaric Conference on Geomorphology, Ostravice, Czech Republic, 17-20 Oct. 2011.

Popescu-Argeşel I. 1980. Microrelieful periglaciar din Masivul Suhard. Studii şi comunicări de ocrotire a naturii. vol. V, Suceava.

Popescu-Argeşel I. 1983. Munții Suhard. Editura Sport-Turism, București.

Posea Gr., Badea L. 1984. România. Unităţile de relief. Regionarea geomorfologică. Editura Ştiinţifică şi Enciclopedică, Bucureşti.

Rădulescu I. 1969. Cristalinul Bistriţei. Structura şi stratigrafia masivului cristalin din partea de nord a Carpaţilor Orientali. SCGGG-Geol. XIV, 1.

Rusu C. 2002. Masivul Rarău-studiu de geografie fizică. Editura Academiei Române, Bucureşti.

Rusu E. 1999. Munţii Bîrgăului studiu fizico-geografic. Editura Univ. Al. I. Cuza, laşi.

Săndulescu M. 1984. Geotectonica României. Editura Tehnică, Bucureşti.

Sîrcu I. 1979. Munţii Rodnei.Editura Academiei, Bucureşti.

*** Arhiva S.C."GEOMOLD" S.A. Câmpulung Moldovenesc.

*** 1987. Geografia României. vol. III. Editura Academiei, Bucureşti. 